\title{
HAK ATAS KEKAYAAN INTELEKTUAL DAN PATEN SAMSUNG SEBAGAI HP DUAL KAMERA PERTAMA
}

\author{
Yosua agus fernando pasaribu \\ 155100080 \\ Fakultas Komputer,785567910 \\ Mahasiswa@institusi.ac.id
}

\begin{abstract}
Hak paten atas kekayaan intelektual sebuah brand berupakan hal penting sebab semua bran berlomba lomba menciptakan itur fitur unggulan untuk dapat bersaing di pasar hp global dan tiap tahun bermunculan trend yang diikuti dengan perkembangan teknologi serta fitur baru di setiap permunculan tipe smartphone baru . oleh karena banyaknya bermunculan fitur baru yang diciptakan oleh sebuah produsen smartphone yang pastinya terus selalu diikuti ataui ditiru oleh produsen smartphone kompetitor lainnha maka dari itu perlunya hak paten untuk kekayaan intelektual fitur dari setiap produsen smartphone yang menciptakan fitur tersebut. Yang kita bahas adalah band samsung dengan fitur dual kameranya,Bukan brand sembaragan, melainkan produsen teknologi asal Korea Selatan yang menggarapnya. Samsung dulu pernah merilis featured phone Samsung SCH-B710 sebagai handphone pertama yang dilengkapi dual kamera

SamsungSCH-B710 merupakan feature phone pertama yang dilengkapi dengan dual kamera. Uniknya, handphone ini dirilis bahkan sebelum perangkat smartphone Apple, iPhone. generasi pertama dirilis. Handphone Samsung SCH-B710 dirilis pada April 2007 sementara iPhone generasi pertama dirilis selang 2 bulan setelahnya, pada Juni 2007.

Kata Kunci : hak atas kekayaan dan paten dual kamera samsung
\end{abstract}




\section{A. INTRODUCTION}

Hak paten atas kekayaan intelektual sebuah brand berupakan hal penting sebab semua bran berlomba lomba menciptakan itur fitur unggulan untuk dapat bersaing di pasar hp global dan tiap tahun bermunculan trend yang diikuti dengan perkembangan teknologi serta fitur baru di setiap permunculan tipe smartphone baru . oleh karena banyaknya bermunculan fitur baru yang diciptakan oleh sebuah produsen smartphone yang pastinya terus selalu diikuti ataui ditiru oleh produsen smartphone kompetitor lainnha maka dari itu perlunya hak paten untuk kekayaan intelektual fitur dari setiap produsen smartphone yang menciptakan fitur tersebut. Yang kita bahas adalah band samsung dengan fitur dual kameranya,Bukan brand sembarag an, melainkan produsen teknologi asal Korea Selatan yang menggarapnya. Samsung dulu pernah merilis featured phone Samsung SCHB710 sebagai handphone pertama yang dilengkapi dual kamera SamsungSCH-B710 merupakan feature phone pertama yang dilengkapi dengan dual kamera. Uniknya, handphone ini dirilis bahkan sebelum perangkat smartphone Apple, iPhone. generasi pertama dirilis. Handphone Samsung SCH-B710 dirilis pada April 2007 sementara iPhone generasi pertama dirilis selang 2 bulan setelahnya, pada Juni 2007.

Berada di kelas featured phone, tentu Samsung SCH-B710 nggak membawa spesifikasi wah untuk saat ini. Handphone ini pun dibekali layar 2,2 inci beresolusi

QVGA 240 x 320 piksel.

Sementara dua buah kamera belakang beresolusi 1.3MP. 
Dari segi desain, Samsung SCHB710 membawa desain

unik dengan layar bisa diputar 180 derajat. Untuk fitur, sama seperti handphone Korea kebanyakan saat itu, Samsung SCH-B710 bisa digunakan untuk menonton TV lewat antena padanya

Dual kamera pada Samsung SCH-

B710 ternyata memiliki nama

khusus, yakni Stereo Camera.

Dengan menggunakan ini, handphone Samsung ini bisa menangkap foto 3D dan menampilkannya pada layar.

Sebelumnya ada juga Sharp mova SH251iS.

Handphone Sharp ini bisa menampilkan gambar 3D namun belum memiliki fitur kamera 3 dimensi ini.

Selanjutnya, booming 3D pada berbagai industri mendorong brand smartphone untuk mewujudkannya, misalnya pada LG Optimus 3D dan HTC Evo 3D pada tahun 2011. bisa dikatakan Samsung SCHB710 sebagai pelopor kamera 3 dimensi sekaligus teknologi dual kamera.

Dilansir darl SITUS SAMSUNG, ternyata bukan smartphone yang pertama menerapkan teknologi dual kamera. Sesuai dengan judul, ternyata yang mengadopsi teknologi canggih ini hanya sekadar handphone alias featured phone saja.

Dan dengan ini samsung mengklaim atau memberi hak paten kepada teknologi dul kamera smartphone nya yang pertama kali yang di sematkan di smartphon seluruh dunia. Dengan terobosan samsung ini berarti hak paten atas kekayaan interlektual itu penting khususnya di smartphone pada era masa kini.

\section{B. CONCLUSION}

bisa dikatakan Samsung SCH-B710 sebagai pelopor kamera 3 dimensi sekaligus teknologi dual kamera.

Dilansir darl SITUS SAMSUNG, ternyata bukan smartphone yang pertama menerapkan teknologi dual kamera. Sesuai dengan judul, ternyata yang mengadopsi teknologi canggih ini hanya 
sekadar handphone alias featured

phone saja. Dan dengan ini

samsung mengklaim atau memberi

hak paten kepada teknologi dul

kamera smartphone nya yang

pertama kali yang di sematkan di

smartphon seluruh dunia.

Dengan terobosan sambung ini berarti hak paten atas kekayaan interlektual itu penting khususnya di smartphone pada era masa kini.

\section{ACKNOWLEDGEMENT}

University Of Indonesia University Of Mitra Indonesia

Telkom University

University Of Mellbourne

Saitama University 
D. REFERENCE (Based ISO 690 )

A. S. Putra And O. M. Febriani, "Knowledge Management Online Application In Pdam Lampung Province," In Prosiding International Conference On Information Technology And Business (Icitb), 2018, Pp. 181-187.

[2] A. S. Putra, O. M. Febriani, And B. Bachry, "Implementasi Genetic Fuzzy System Untuk Mengidentifikasi Hasil Curian Kendaraan Bermotor Di Polda Lampung," J. Sist. Inf. Dan Manaj. Basis Data, Vol. 1, No. 1, Pp. 21-30, 2018.

[3] O. M. Febriani And A. S. Putra, "Sistem Informasi Monitoring Inventori Barang Pada Balai Riset Standardisasi Industri Bandar Lampung," J. Inform., Vol. 13, No. 1, Pp. 90-98, 2014.

[4] Putra, Arie Setya. "2018 Artikel Struktur Data, Audit Dan Jaringan Komputer." (2018).

[5] Putra, A. S. (2018, July 17). Paperplain Fundamental Create Application With Borland Delphi 7.0 University Of Mitra Indonesia. Retrieved From Osf.Io/Pbrn9.

\section{E. REFERENCE (Based APA)}

Putra, A. S., Aryanti, D. R., \& Hartati, I. (2018, November). Metode SAW (Simple Additive Weighting) sebagai Sistem Pendukung Keputusan Guru Berprestasi (Studi Kasus: SMK Global Surya). In Prosiding Seminar Nasional Darmajaya (Vol. 1, No. 1, pp. 85-97).

Sari, D. P., Febriani, O. M., \& Putra, A. S. (2018, November). Perancangan Sistem Informasi SDM Berprestasi pada SD Global Surya. In Prosiding Seminar Nasional Darmajaya (Vol. 1, No. 1, pp. 289-294).

Putra, A. S. (2018). Paperplain: Execution Fundamental Create Application With Borland Delphi 7.0 University Of Mitra Indonesia.

Putra, A. S., Sukri, H., \& Zuhri, K. Sistem Monitoring Realtime Jaringan Irigasi Desa (JIDES) Dengan Konsep Jaringan Sensor Nirkabel. IJEIS (Indonesian Journal of Electronics and Instrumentation Systems), 8(2), 221232.

Darmawan, A., Yuliawati, D., Marcella, O., \& Firmandala, R. (2016). Sistem Absensi dan Pelaporan Berbasis Fingerprint dan SMS Gateway. EXPLORE, 7(1). 
Febriani, O. M., Wahyuni, T., \& Yusuf, S. (2017). DESIGN OF WEBSITEBASED INFORMATION SYSTEM FOR EDOCUMENT

ADMINISTRASI IN THE
COMMUNITY SERVICE UNIT (A Case Study at Rajabasa District). INTERNATIONAL JOURNAL OF COMPUTERS \& TECHNOLOGY, 16(7), 7010-7020.

Febriani, O. M., \& Wahyuni, T. (2017, October). PERANCANGAN SISTEM E-DOCUMENT ADMINISTRASI LOGBOOK PENELITIAN PADA UNIT LAYANAN DI BANDAR LAMPUNG. In Prosiding Seminar Nasional Darmajaya (Vol. 1, No. 1, pp. 187-194).

Febriani, O. M., \& Permadi, A. B. (2017). Implementasi Sistem Aplikasi Data Bimbingan dan Pelanggaran Siswa pada Sekolah Menengah Atas di Lampung Tengah dengan Metode Analisis dan Desain Sistem Terdistribusi (SSAD). EXPERT, 7(1).

Febriani, O. M., \& Ambarwati, L. (2015). PERANCANGAN APLIKASI PENGOLAHAN DATA PENJUALAN UKM KELANTING KHAS TELO DESA SIDOHARJO KECAMATAN JATI AGUNG KABUPATEN LAMPUNG SELATAN. Jurnal Teknologi Informasi dan Bisnis Pengabdian Masyarakat Darmajaya, 1(1), 77-95.

Febriani, O. M. (2015). Rancang Bangun Aplikasi Ecommercemenggunakan Freewebstore pada UKM Kelanting di Desa Sidoharjo Lampung Selatan. Prosiding Sembistek 2014, 1(02), 446-458. 